Georgia State University

ScholarWorks @ Georgia State University

\title{
Extending the Vision: Three Women Who Saw the Future of Music Education
}

Patrick K. Freer

Georgia State University, pfreer@gsu.edu

Diana R. Dansereau

Boston University, drd1@bu.edu

Follow this and additional works at: https://scholarworks.gsu.edu/music_facpub

Part of the Music Commons

\section{Recommended Citation}

Freer, Patrick K. and Dansereau, Diana R., "Extending the Vision: Three Women Who Saw the Future of Music Education" (2007). Music Faculty Publications. 25.

https://scholarworks.gsu.edu/music_facpub/25

This Article is brought to you for free and open access by the School of Music at ScholarWorks @ Georgia State University. It has been accepted for inclusion in Music Faculty Publications by an authorized administrator of ScholarWorks @ Georgia State University. For more information, please contact scholarworks@gsu.edu. 
[AH]Extending the Vision: Three Women Who Saw the Future of Music Education

[BY-LINE]By Patrick K. Freer and Diana R. Dansereau

[LEAD-IN]The example and words of three MENC presidents can still inspire and rally our profession today.

[BIO]Patrick K. Freer is head of the music education division at Georgia State University, Atlanta. He can be reached at pfreer@gsu.edu. Diana R. Dansereau resides in Providence, RI where she teaches and conducts research. She can be reached at d_dansereau@yahoo.com.

Twelve women have led MENC: The National Association for Music Education, including current president Lynn Brinckmeyer--six of them in the first fifty years of MENC's history. Frances Elliott Clark, known as the "Mother of the Conference," oversaw the founding of the Music Supervisors' National Conference (MSNC) in 1907 at a gathering in Keokuk, Iowa. $<+>1<+>$ Two women served the organization as president during its first quarter century: Henrietta G. Baker (presidency 1912[end]13) and Elizabeth Casterton (1913[end]14). This article highlights the other three female presidents of the Music Educators National Conference (as renamed in 1934) who served in the first fifty years of the organization: Mabelle Glenn (1928[end]30), Lilla Belle Pitts (1942[end]44), and Marguerite V. Hood (1950[end]52). The recent election of Lynn Brinckmyer to the MENC presidency encouraged us to consider the role that other women presidents had played in the development of the organization. Glenn, Pitts, and Hood emerged as particularly interesting to us because their presidencies coincided with periods of enormous growth within our profession. As we reviewed MENC's history and looked toward the future, it seemed important to introduce a new generation of music educators to the contributions of these visionary women. 
The period from the 1920 s to the 1950 s saw great expansion in the membership, structure, and ideals of the organization as it was forced to confront issues of relevancy and purpose. A number of pivotal events of the twentieth century occurred during the presidencies of the women profiled in this article, including the Great Depression, which began in 1929 (Glenn), and the United States' entry into World War II (Pitts). During Hood's presidency, MENC began to consider its global role in music education while reaffirming its commitment to music education for all pupils in the United States.

Growth and change did not always occur easily during these decades, and vigorous debate filled the pages of MENC publications. In recognition of MENC's centennial, this article is focused exclusively on the writings of these women published in the $<$ I $>$ Music Supervisors' Journal $<\mathrm{I}>$, (later renamed $<\mathrm{I}>$ Music Educators Journal $<\mathrm{I}>$ ) and the organization's various proceedings and yearbooks. These presidents contributed a combined total of more than sixty-six significant writings to MENC, each of which was systematically analyzed for this article. The themes and topics presented here offer a glimpse into the significant influence these women had on music education before, during and after their presidencies.

[SH]Mabelle Glenn: A View of Pedagogy

\section{[INSERT PHOTO OF GLENN]}

Longtime supervisor of music instruction for the Kansas City (Missouri) public schools, Mabelle Glenn brought considerable practical experience to her role as adviser to the profession: "Read what everybody else thinks and with this as a background do your own thinking. If you are sincerely looking for truth, you will be more likely to find it in the school room than at a desk remote from children." $<+>2<+>$ As MSNC approached its 1932 silver anniversary, Glenn wrote, "We will improve music education and extend its influence only by open-minded thought about it [eli] We cannot exist on past achievement. Neither should we be satisfied to use the methods and organization which were adequate ten years ago." $<+>3<+>$ 
Many of Glenn's writings concerned the impact of pedagogical techniques on children's future musical endeavors. She frequently chided the profession for not keeping overarching purposes in mind: "If music is to function in American life to a greater extent than it is now functioning, we [eli] must 'extend our vision beyond keeping pace with the present.' We must see in public school music a means of feeding man's need for beauty, not a stunt for arousing transient enthusiasm. Do we fear bringing joy to the music lesson?" $<+>4<+>$ "Psychologists tell us that 'children $<\mathrm{I}>$ learn $<\mathrm{I}>$ only when there is joy in the learning.' This may account for the many who have come through our music classes in the schools, yet have little desire for music and no ability in making music after their school days are over." $<+>5<+>$

Glenn later wrote more specifically about the relationship between pedagogical methods and the nature of music:

[UFEXT]While we may rightly blame the trend of the times for the fact that our music instruction has not germinated and continued to bear fruit in American adult life, we must charge some of this failure to the way our subject has been approached. Many times we make the mistake of applying to the teaching of music methods suitable to the teaching of wholly different kinds of materials. When music is buried under technique it is seldom resurrected. We fail when we try to teach the grammar of an art before teaching an art itself. $<+>6<+>$ [UFTEX]

As her career progressed, Glenn became increasingly emphatic about the child's need for individual discovery, writing that "play to the child is life; and we believe that its equivalent for the adult is creative art," $<+>7<+>$ adding, "whether this enchantment is discovered or not depends on the musical intelligence we use in our work." $<+>8<+>$

Glenn aimed most of her pedagogical efforts toward the improvement of vocal instruction in schools. "Alas," she wrote in 1928, "too often one is less at peace with God and man after the church choir sings the anthem than before it began." $<+>9<+>$ She encouraged choral teachers to recall a choral "moment when 'your soul was dilated and your universe enlarged' [and] you will 
remember that the director did not come between his singers and the music [eli] It was the music that left an imprint on your heart and mind, and that is as it should be. The director's attitude should be that of helping his pupils make their own aesthetic discoveries." $<+>10<+>$ Glenn pursued a similar argument when referring to sight-reading: "It goes without saying that only the best material has a place in any music class. But if this music is presented as so many black notes arranged in an intricate design on white paper, it may be performed with skill and yet fail completely as a musical experience." $<+>11<+>$

Glenn wrote repeatedly about the connection of learning and experience, imploring music educators to "think of the primary child's singing of the pitter, patter, patter of the rain, or the trot, trot, trotting of his little pony. Each song does more to bring tones to the lips and tip of the tongue than any half-dozen stupid exercises. What could develop a more beautiful legato than some of the little child's lullaby songs?" $<+>12<+>$ Unfortunately, "most teachers of today are victims of informational and drill education, and it is hard for them to break away from teaching rhythm through mathematics. Therefore, they go from the symbol to the experience instead of going from the experience to the symbol, and spend time in explanations which mean nothing." $<+>13<+>$

To interrupt this cycle, Glenn urged teachers to notice "the importance of [eli] the child's bodily expression of $<\mathrm{I}>$ his own $<\mathrm{I}>$ conception of the music. How many teachers are guilty of projecting their own conceptions to such an extent that their classes get very little chance of developing any power other than that of imitation." $<+>14<+>$ "Would that we [eli] were more interested in child growth than in our stunts, that we were more concerned with building desirable attitudes than in cramming isolated facts; and above all else, would that we might keep ourselves in tune with music itself because 'beauty dwells as much in the one feeling it as in the thing sensed." $<+>15<+>$

Glenn felt that these pedagogical procedures could negatively influence lifelong learning, writing that "the study of music involves much more than learning to play [an instrument] or to glibly read by syllables, and if these alone have represented public school music, little has been 
done to stimulate those faculties alluded to as "education." $<+>16<+>$ She extended this reasoning to a music education based solely on performance: "As long as instruction is given in the name of music which really develops only a technique of performance--either vocal or instrumental--and completely ignores musicianship, there is very grave question as to its place in an educational system." $<+>17<+>$

Glenn's view was that the music teacher's primary responsibility was to ignite a passion for music in America's students. This, she felt, would never occur by "pouring in information and imposing our own judgment," but by emphasizing that "never before has there been such a need for independent thinking and discrimination in music listening as there is today." $<+>18<+>$ She believed that musical independence was inextricably tied to musical practice beyond the school: "If a boy is led to look on his musical development as $<\mathrm{I}>$ his $<\mathrm{I}>$ undertaking, for which he can and does assume responsibility, he will put enough initiative into the undertaking to make it a habit." $<+>19<+>$ Achieving this goal would require music teachers to articulate the primary aim of their pedagogy. "Is it to teach facts about music and develop skill in reading music, or is it to awaken and stimulate joy and interest? [eli] You must introduce music to these children as a thing of beauty to be enjoyed and not as something to be struggled with." $<+>20<+>$ "In music, children, hungry for beauty, too often are given chronological facts and dates [eli] Building desirable attitudes toward music is the first aim of all music education. This objective must be kept in mind through every activity." $<+>21<+>$ Glenn wrote that, "America is in the midst of a vigorous change in education [eli] Instead of subject matter to be learned and tests of achievement to be passed [eli] child interests and needs are in the spotlight [eli] 'What the book says about it' has given place to 'what I think about it' in the modern class room." $<+>22<+>$

Glenn used her presidency to challenge music educators to consider the relationships between music, instructional methods, and the goals of music education. "The test of our teaching is not what pupils do when we are present but what they do when our presence is removed. We must admit failure if interest in music ceases on graduation." $<+>23<+>$ Glenn promoted the role of active music-making as the basis for music learning, providing one of her most poignant 
statements when writing about the impact of the radio on the musical lives of Americans: "If an individual has had a thrill in making music, he will never be completely satisfied with the turn of a knob." $<+>24<+>$

[SH]Lilla Belle Pitts: A View toward Developing Aims and Purposes [INSERT PITTS PHOTO.]

Lilla Belle Pitts continued the themes evident in Mabelle Glenn's writings and responded to the calls for educational reform by espousing the integration of music and other academic subjects:

[UFEXT]There are few among us who would advocate keeping music so enthroned as a special subject as to render it powerless to serve its own best interests as well as those of the curriculum as a whole. Isolation is uncompromising in its connections, and music $<\mathrm{I}>$ isolated $<\mathrm{I}>$ would imply music teaching so set apart as to be unable to function for the purposes of secondary education, likewise cut off from its full meaning and usefulness in terms of its own processes. $<+>25<+>[$ UFEXT]

This pedagogical focus broadened over time into a philosophical dialogue about the aims and purposes of music education, setting the stage for the emergence of Pitts as the quintessential leader to whom the profession would turn for many decades: "Music educators are wondering just what the status of music will be [eli] Is music to be made correlative or accessory to other school subjects, operating in accordance with their general purposes and requirements? Or will music be allowed to maintain its status as a special subject with the privilege of setting up purposes and standards within its own processes? Cannot we venture the answer $<\mathrm{I}>\mathrm{yes}<\mathrm{I}>$ to each question?" $<+>26<+>$

Pitts was convinced that music education's purposes and curricula were inseparable: "If we are to be ready to meet the challenge of universal art education for $<\mathrm{I}>$ all $<\mathrm{I}>$ [eli] we shall have 
to devote a fair measure of our time, attention, and talent to the general integrating phases of music teaching. This does not mean to discount or to discourage the performance aspects of music education nor the special techniques for special purposes. But it does question injudicious differentiation, too early specialization and overspecialization." $<+>27<+>$ Like Glenn, Pitts questioned music education's preoccupation with performance, wondering "What is the chief purpose of music in public education? Have we lost sight of educational processes in too fixed a gaze upon refining musical products?" $<+>28<+>$ Two decades later, in 1958, Pitts answered these questions with an emphatic statement: "The ultimate goal of music education is identical with the great American dream, namely, that every man, woman and child in this country is accorded the right and the obligation to improve American culture by improving himself or herself. The continuous $<\mathrm{I}>$ purpose $<\mathrm{I}>$ of music $<\mathrm{I}>$ in $<\mathrm{I}>$ education is to use education $<\mathrm{I}>$ through $<\mathrm{I}>$ music as a means of attaining this ideal." $<+>29<+>$

The journey Pitts took between her questions and her answers included the presidency of MENC during the Second World War, which had considerable influence on events during her term. In response to the entry of the United States into the war, Pitts wrote: "Music performs its greatest service when used by all of a people to communicate and to further their common purposes and ideals. Knowing this, each and every one of us in the field of music education should redouble his efforts to provide increased opportunities for people of every age, interest, and occupation, in school, or out, in service or in civilian life, to participate in making and enjoying music." $<+>30<+>$ Pitts eloquently addressed her beliefs about music's broader purpose during times of conflict, stating that "the human spirit is not confined by the boundaries of any one nation, language, nor period of time; nor is it limited by any one system of political or social beliefs and practices. It is, accordingly, entirely reasonable to suppose that music has the power to become a force in developing better understandings in a world of interdependent peoples." $<+>31<+>$

Pitts calmed and reassured music educators while simultaneously urging a reexamination of goals and purposes. "We have produced the most brilliant and expert musical performance by the 
largest number of student groups of any other nation at any other time in history [eli] But excellence of musical skills is not now the burning question. Confronting us are changes that are uprooting cultural patterns on all sides. So what matters most now is that we defend our fundamental belief in the power of music to perform a major service, first in helping keep open the way to, second in helping create, the richest and freest life for all." $<+>32<+>$ While Pitts was president, the United States government urged educators to assist the war effort through curricular content and instructional methods. MENC responded by supporting a call for patriotic music that Pitts viewed as an opportunity for composition. She began by stating that

[UFEXT]while high-school boys and girls are too immature to express the profound social philosophy, exaltation of high purpose, and other deeply moving emotions evolving out of the present world conflict, nevertheless something constructive in its effect upon the richness of our ongoing culture should be expected from them. The gamut of potential subject matter for songs growing out of and reflecting present-day thoughts and experiences includes both the little and the big things, both simple and profound emotions, both humor and high seriousness [eli] the whole broadening range of experiences, mental and physical, that the young people of today are undergoing. Only let the songs be sincere and fine, let them stay clear of cheapness. $<+>33<+>[$ UFTEX]

Fifteen years later, as MENC entered its second half-century, Pitts chaired a committee that resulted her final major $<\mathrm{I}>$ Music Educators Journal $<\mathrm{I}>(<\mathrm{I}>\mathrm{MEJ}<\mathrm{I}>)$ publication. She made reference to the beginning of the Cold War between the United States and the Soviet Union, returning to themes she expressed in response to the outbreak of World War II: "Music education is being urged as never before to bring out and to emphasize the human, social and esthetic values that are inherent in music. Employment of music during world shaking periods of stress and strain is a familiar memory to all who have lived through one or more periods of war. Today, music is serving as we endure the wearing uncertainties of a cold war. In such a time we realize, 
more than ever before, how important it is to live with mutual respect at home and abroad, with people whose cultures, beliefs and ideals, differ from one's own." $<+>34<+>$

During her presidency, Pitts developed plans for the largest expansion of MENC's membership and structure in the organization's history, announcing, [UFEXT]People of vision and courage view the future with faith. Instead of holding back, they are reaching out to make contacts, to talk with others about the new paths that will have to be charted along unfamiliar ways. The latter is the spirit that has always distinguished the leaders of the Music Educators National Conference, and it is this quality of mind and spirit that has built a proud past upon which the present that we enjoy is founded [eli] Our organization already has become both national and international in the scope of its influence. We have every reason to envision an eventual future in terms of world-wide service. Therefore, we can no longer go on the assumption that the broad outlines of a system adequate for the past will suffice to meet the needs of future developments. $<+>35<+>$

Several years later, that same attention to planning would mark the presidential tenure of Marguerite V. Hood.

[SH]Marguerite V. Hood: A View Toward Focus and Planning [INSERT HOOD PHOTO.]

Marguerite V. Hood's first contributions to MENC grew from her role as Montana's state supervisor of music and her passionate advocacy for music in rural schools. As MENC president, she expanded this view to promote equality of musical opportunity for all students in the United States and across the globe. These burgeoning themes were evident in her first MENC article, written in 1931:

[UFEXT]We talk much about the psychology of individual differences, and stress the value of music to a child as a means of developing his power and ability as an individual [eli] But theory 
and practice are two different things when it comes to the listening lesson--we forget what experience has taught us, both as music lovers and as educators. Our main ambition seems to be to lead the group as a whole to $<\mathrm{I}>$ our $<\mathrm{I}>$ idea of an understanding of the music being studied, and not to a real, personal understanding of the music as it may appeal to each individual. $<+>36<+>[$ UFTEX]

In words echoing those of Glenn and Pitts, Hood returned to this theme thirty-one years later: "The emphasis on performance in the music curriculum of the average American high school has been receiving a steadily increasing amount of criticism [eli] In many schools the music curriculum is limited to the activities of performing organizations, thus automatically shutting non-performers out of musical contacts while in school." $<+>37<+>$

As the United States emerged from World War II and MENC's expansion plans moved forward, Hood cautioned that "when we neglect, as we consistently do, certain geographic areas, and certain age-level groups, in distributing musical opportunities, we are not only cheating many American children of a valuable part of their background as well-balanced individuals, but we are also leaving untapped a great reservoir of musical resources." $<+>38<+>$ She continued, "We are continually being reminded of our responsibilities as American citizens--responsibilities within our own country for postwar reconversion in industry and in living, and in international responsibilities for diplomatic leadership, for economic planning and for sharing our goods with the needy of the world." $<+>39<+>$

Hood's presidency was marked by MENC striving to fulfill the democratic aims of music education both in America and abroad. Though the organization sought to define itself in these terms, Hood warned that

[UFEXT] the real danger to music education comes [eli] from within ourselves. Unless we look out, that very concentrated interest and whole-hearted love of our work which has made us progress with such remarkable speed as a profession will be our undoing. It takes more than 
good teaching today to make a successful recognized profession of music education. It takes sufficient interest on the part of the music educators to keep themselves intelligently informed about what is happening in music as a whole, among composers, performers, etc.; about what comes and goes in beliefs regarding general liberal education. It takes still more--it demands farsighted thinking and action. $<+>40<+>$ [UFTEX]

[SH]A Collective Focus: Music Education's Relevancy for Youth

The question of relevancy has been a dominant theme through most of MENC's history. Hood asked, "Why is there such a distinct gap between the music heard in school and that chosen by the average child for enjoyment?" $<+>41<+>$ She proposed that "whether we approve of this taste or not, we cannot disregard it--our best success will come from working through it. Music must be connected in some way with a personal knowledge, feeling or idea on the part of the average listener, otherwise it is only superficially $<\mathrm{I}>$ heard $<\mathrm{I}>$, not $<\mathrm{I}>$ listened $<\mathrm{I}>$ to." $<+>42<+>$

In one of her early articles, Pitts addressed the then-popular music and dance phenomenon known as the jitterbug. Her comments and analysis remain timelessly relevant. Pitts began by asking,

[UFEXT]Is the jitterbug, whether a passing phenomenon or a permanent affliction, any of our business? [eli] We will get nowhere deploring jitterbugs. Our business is to find out $<\mathrm{I}>$ why $<\mathrm{I}>$ the jitterbug [eli] Whether we approve or disapprove, our young folk are making this aspect of their environment important to us because it is important to them. The reasons for the latter seem to me fairly clear. For one thing, there is a kind of kinship between American youth and American popular music. On the whole, this is music made $<\mathrm{I}>$ by $<\mathrm{I}>$ the young $<\mathrm{I}>$ for $<\mathrm{I}>$ the young. The best of it teems with life and energy. Its idiom is one of immaturity, making up in vitality for what it lacks in eloquence. Like youth, it is in the making. $<+>43<+>$ [UFTEX] 
Pitts reminded $<\mathrm{I}>\mathrm{MEJ}<\mathrm{I}>$ readers that "music educators and commercial entertainers have one thing in common: the opportunity to induce smiles, to evoke moods of happiness and to make occasion for having fun--a function not to be despised in a world sorely in need of every encouragement to believe in the wholesomeness of laughter and the goodness of enjoyment." $<+>44<+>$

\section{[SH]The Constancy of Change}

These three women served MENC during periods of unprecedented change. Glenn wrote, "We are living in a world that is undergoing extensive and accelerated change. Schools must meet new situations daily and change of thought must go ahead to show the way. In the change of thought among leaders in education, music is finding a definite place." $<+>45<+>$ Hood urged that MENC welcome change as an opportunity to ask itself important questions: "Can we justify the way our time is spent in today's music classes? Are we considering the true place of the work we are doing in the total life-picture of the school child? What have we done for the children in musically neglected areas?" $<+>46<+>$ In words that could have been written in 2007 , Hood urged music educators to "give our profession the benefit of a thorough study. Maybe reconversion for a new type of product will be the answer. Certainly we must be ready for an era of change." $<+>47<+>$

As World War II raged, Pitts encouraged MENC to look forward to the challenges of a changing world:

[UFEXT]Another informal way of making friends though music is being put into practice by our soldiers and sailors who are scattered north, east, south and west over the world's battle fronts [eli] Our men and women in the armed forces are not only $<\mathrm{I}>$ taking $<\mathrm{I}>$ their musical backgrounds and attitudes with them to far places, but they are $<\mathrm{I}>$ getting $<\mathrm{I}>$ new experiences and points of view which will eventually have an effect upon the horizons of music education 
back home. $<\mathrm{I}>$ Will they find us as ready to meet them on their new ground as citizens of an expanded world? $<$ I $>$ [emphasis original] $<+>48<+>$ [UFTEX]

$[\mathrm{SH}]$ Extending the Vision

Mabelle Glenn, Lilla Belle Pitts, and Marguerite V. Hood each rallied the profession, urged it to embrace change, and positioned it for growth. While MENC looks forward to its second century, a look backward may provide guidance, direction, and professional focus. As Hood wrote, "The child who is musical will profit by any instruction we give him, carry it into his home, and increase the general musical understanding there. But our motto is not 'Music for the $<$ I $>$ musical $<$ I $>$ child'--it is 'Music for $<$ I $>$ every $<$ I $>$ child."' $<+>49<+>$ 
[Sidebar]Biographical Highlights

[SH]Mabelle Glenn (1881[end]1969)

[bul] Received a Bachelor of Music degree from Monmouth College, Monmouth, Illinois (1908)

[bul] Received an honorary doctorate from Chicago Musical College, Chicago, Illinois (1930)

[bul] Served as supervisor of music for the public schools of Monmouth, Illinois (1908-1912),

Bloomington, Illinois (1912-1921) and Kansas City, Missouri (1921-1950)

[bul] Was an author of MENC's Child's Bill of Rights in Music (1950)

[bul] Served as president of the Music Supervisors National Conference from 1928 to 1930

[SH]Lilla Belle Pitts (1884[end]1970)

[bul] Taught music for the Amarillo, Texas (1910-1914) and Dallas, Texas (1914-1921) public schools and the Grover Cleveland Junior High School in Elizabeth, New Jersey (1921-1923)

[bul] Worked as an educational representative for Columbia Records (1921-1923)

[bul] Received a Bachelor of Science in music education from Teachers College of Columbia University, New York, NY (1935)

[bul] Joined the Teachers College faculty (1938)

[bul] Served as vice president of MENC from 1938 to 1942 and president of MENC from 1942 to 1944

[SHMarguerite V. Hood (1903[end]1992)

[bul] Received a Bachelor of Arts degree from Jamestown College, Jamestown, North Dakota (1923)

[bul] Received a Master of Music from University of Southern California, Los Angeles, California (1941)

[bul] Received an honorary doctorate from Jamestown College

[bul] Served as Montana's first state supervisor of music (1930-1942) 
[bul] Served on the faculty of the University of Michigan, Ann Arbor (1942-1972) and as chair of the Ann Arbor, Michigan, Public Schools music department (1942-1958)

[bul] Served as president of Music Educators National Conference (MENC) from 1950 to 1952 
[SIDEBAR]For Further Reading

[SH1]About These MENC Presidents

Blanchard, Gerald L. "Lilla Belle Pitts: Her Life and Contribution to Music Education.” EdD diss., Brigham Young University, 1966.

Cooper, Shelly C., "Marguerite Vivian Hood (1903[end]1992): Her Life and Contributions to Music Education.” DMA diss., Arizona State University, 2004.

Holgate, George Jackson. "Mabelle Glenn: Her Life and Contributions to Music Education." EdD diss., University of Southern California, 1962.

Howe, Sondra Wieland. "Leadership in MENC: The Female Tradition." $<$ I $>$ Bulletin of the Council for Research in Music Education< $<141$ (summer 1999): 59[end]65.

[SH1]Suggested Articles by These MENC Presidents

[SH2]Mabelle Glenn

"Creative Education in Music." $<\mathrm{I}>$ Music Supervisors Journal $<\mathrm{I}>15$, no. 5 (1929): 15, 17, 19, 21.

"What is 'Music Appreciation'? A Symposium." $<\mathrm{I}>$ Music Educators Journal $<\mathrm{I}>22$, no. 4 (1936): 15 .

[SH2]Lilla Belle Pitts

"Music Education, Isolated or Integrated." $<\mathrm{I}>$ Music Educators Journal $<\mathrm{I}>24$, no. 1 (1937): 33, $71[$ end $] 73$. 
"Widening Horizons for Music Education." $<\mathrm{I}>$ Music Educators Journal $<\mathrm{I}>30$, no. 4 (1944): $17[$ end $] 19,54[$ end $] 55$.

[SH2]Marguerite V. Hood

"Music in American Education: Our Heritage Demands Action, Not Defense." $<$ I $>$ Music

Educators Journal<I>38, no. 4 (1952): 17[end]19.

"Our Changing School Music Program," $<\mathrm{I}>$ Music Educators Journal $<\mathrm{I}>$ 48, no. 4: 49[end]50, $74,76[$ end $] 78$. 
$[\mathrm{SH}]$ Notes

1. MENC, "MENC Past National Presidents."

www.menc.org/information/members/fame/presbricks.html.

2. Mabelle Glenn, "Some Early Supervisory Experiences," $<\mathrm{I}>$ Music Supervisors Journal $<\mathrm{I}>$ 13, no. 2 (1926): 21.

3. Mabelle Glenn, "Public School Music Comes of Age," in $<\mathrm{I}>$ Journal of Proceedings of the Music Supervisors National Conference $<$ I $>$, ed. Paul J. Weaver, 27[end]32 (Ithaca, NY: Cornell University, 1930), 28[end]29.

4. Mabelle Glenn, "The School Administrator and the Music Program," $<\mathrm{I}>$ Music Supervisors Journal $<\mathrm{I}>15$, no. 2 (1928): 19 .

5. Mabelle Glenn, "Trends in Music Education," in $<\mathrm{I}>$ Yearbook of the Music Supervisors National Conference $<\mathrm{I}>$, 258[end]262 (Chicago: Music Supervisors National Conference, 1933), 258.

6. Glenn, "Public School Music," 29.

7. Glenn, "Public School Music," 28.

8. Mabelle Glenn, "Singing in Elementary Schools and Junior High Schools," in $<$ I $>$ Yearbook of the Music Supervisors National Conference $<$ I $>$, 100[end]103 (Chicago: Music Supervisors National Conference, 1933), 103.

9. Mabelle Glenn, "A New Goal in Ensemble Singing," $<\mathrm{I}>$ Music Supervisors Journal $<\mathrm{I}>15$, no. 1 (1928): 67.

10. Glenn, "Singing in Elementary Schools," 100[end]101.

11. Mabelle Glenn, "National Music Discrimination Contest: Results and Conclusions," $<\mathrm{I}>$ Music Supervisors Journal<I $>18$, no. 5 (1932): 34.

12. Glenn, "Singing in Elementary Schools," 101.

13. Mabelle Glenn, "Demonstration of Creative Rhythm," in $<\mathrm{I}>$ Yearbook of the Music Supervisors National Conference $<\mathrm{I}>$, 311[end]314 (Chicago: Music Supervisors National Conference, 1932), 311. 
14. Mabelle Glenn, Review of $<\mathrm{I}>$ Music Appreciation for Little Ones $<\mathrm{I}>,<\mathrm{I}>$ Music Supervisors' Journal<I> 7, no. 1 (1920): 28 .

15. Mabelle Glenn, "Creative Education in Music," $<\mathrm{I}>$ Music Supervisors Journal $<\mathrm{I}>15$, no. 5 (1929): 21.

16. Glenn, "Music Appreciation for Little Ones," 28.

17. Glenn, "National Music Discrimination Contest," 34.

18. Glenn, "Public School Music,” 30[end]31.

19. Glenn, "Public School Music,” 29.

20. Mabelle Glenn, "What It Means to Be a Music Supervisor," <I $>$ Music Supervisors Journal<I $>14$, no. 1 (1927): 51 .

21. Mabelle Glenn, et al., "What is 'Music Appreciation'?: A Symposium," $<\mathrm{I}>$ Music Educators Journal $<\mathrm{I}>22$, no. 4 (1936): 15.

22. Glenn, "Creative Education in Music," 15.

23. Glenn, "Public School Music,” 29.

24. Glenn, "Public School Music," 29.

25. Lilla Belle Pitts, "Music Education, Isolated or Integrated," $<\mathrm{I}>$ Music Educators Journal $<\mathrm{I}>24$, no. 1 (1937): 33 .

26. Pitts, "Music Education, Isolated or Integrated," 71.

27. Pitts, "Music Education, Isolated or Integrated," 72.

28. Lilla Belle Pitts, "Music and Education," $<\mathrm{I}>$ Music Educators Journal $<\mathrm{I}>25$, no. 4 (1939): 16 .

29. Lilla Belle Pitts, "Purposes and Goals of Music Education in 1958," $<\mathrm{I}>$ Music Educators Journal $<\mathrm{I}>44$, no. 5 (1958): 19.

30. Lilla Belle Pitts, "With Faces Lifted Up," $<\mathrm{I}>$ Music Educators Journal $<\mathrm{I}>28$, no. 4 (1942): 12.

31. Lilla Belle Pitts, "Widening Horizons for Music Education," $<$ I $>$ Music Educators Journal $<\mathrm{I}>30$, no. 4 (1944): 19. 
32. Lilla Belle Pitts, "Music in a Changing World," $<\mathrm{I}>$ Music Educators Journal $<\mathrm{I}>29$, no. 1 (1942): 15 .

33. Lilla Belle Pitts, "Creative Music and the War," $<$ I $>$ Music Educators Journal $<\mathrm{I}>29$, no. 3 (1943): 7.

34. Pitts, "Purposes and Goals," 21.

35. Lilla Belle Pitts, "Expanding Horizons," $<\mathrm{I}>$ Music Educators Journal $<\mathrm{I}>29$, no. 5 (1943):

9.

36. Marguerite V. Hood, “'Practical' Listening Lessons--Are They Possible?” $<\mathrm{I}>$ Music Supervisors' Journal<I>17, no. 5 (1931): 22 .

37. Marguerite V. Hood, "Our Changing School Music Program," $<\mathrm{I}>$ Music Educators Journal $<\mathrm{I}>48$, no. 4 (1962): 78 .

38. Marguerite V. Hood, et al., "Needs, Opportunities, Plans, and Prospects--A Symposium: Our Musical Resources" $<$ I $>$ Music Educators Journal<I $>$ 32, no. 6 (1946): 16.

39. Hood et al., "Needs, Opportunities," 16.

40. Marguerite V. Hood, "Music in American Education: Our Heritage Demands Action, Not Defense," $<$ I $>$ Music Educators Journal $<$ I $>38$, no. 4 (1952): 19.

41. Hood, "Practical' Listening Lessons," 21.

42. Hood, "Practical' Listening Lessons," 58.

43. Lilla Belle Pitts, "Music and Modern Youth," $<$ I $>$ Music Educators Journal $<\mathrm{I}>26$, no. 2 (1939): 18)[end]19.

44. Pitts, "Music and Modern Youth," 68.

45. Glenn, "Public School Music,” 27.

46. Marguerite V. Hood, et al., "Valedictory--Salutatory: Messages from the Retiring and Incoming Presidents of the Division Conferences," $<\mathrm{I}>$ Music Educators Journal $<\mathrm{I}>31$, no. 6 (1945): 20 .

47. Hood et al., "Valedictory--Salutatory," 21.

48. Pitts, "Widening Horizons," 19. 
49. Hood, “"Practical' Listening Lessons,” 21. 
$[\mathrm{BOX}]$

$<\mathrm{I}>\mathrm{MEJ}<\mathrm{I}>$ Centennial Series

In 2007, MENC's hundredth anniversary, each issue of $<\mathrm{I}>\mathrm{MEJ}<\mathrm{I}>$ will feature a special article celebrating the centennial in a series guest-edited by Patrick K. Freer. Each article is intended to reflect on the past one hundred years and consider where we might go from here. The following articles make up this special series:

[bul] "Reflections on Fifty Years of Publishing with MENC" by Bennett Reimer, January 2007 $<\mathrm{B}>$ [bul] "Extending the Vision: Three Women Who Saw the Future of Music Education" by Patrick K. Freer and Diana R. Dansereau, March 2007<B>

[bul] "Democracy in Music Education" by Randall Allsup, May 2007

[bul] "Keokuk I to Keokuk II: A Story of Global Dimensions" by Marie McCarthy, September 2007

[bul] "Music Education at the Tipping Point" by John Kratus, November 2007 